colitis. But repeated observations of other subjects will be necessary to settle this crucial issue.

\section{Summary}

A pilot study previously reported (Salem et al., 1964) revealed that the small-intestinal mucosa often showed varying degrees of villous atrophy in patients with ulcerative colitis and that the faecal fat was likewise abnormally high in some patients. Similarly, the gastric mucosa sometimes showed superficial gastritis.

The study has now been extended to 60 patients with ulcerative colitis. In order to establish a yardstick of normality, a control group of 55 patients suffering from irritable-colon syndrome, psoriasis, or anaemia have also been studied.

Almost all the control subjects yielded small-intestinal biopsy specimens which were completely normal, while the others showed only minor villous abnormalities. By contrast, the incidence of villous abnormalities was high in ulcerative colitis and the degree of abnormality was often pronounced.

There was close connexion between the clinical state of activity of the ulcerative colitis and the condition of the smallintestinal biopsy specimen. When the ulcerative colitis was in remission small-intestinal abnormalities were minor in degree, whereas in severe attacks of ulcerative colitis the small-intestinal biopsy specimen frequently showed partial villous atrophy.

Similarly, the daily faecal fat excretion and a modified D-xylose test of small-intestinal absorption were often abnormal in actual attacks of ulcerative colitis. There is a good, though not perfect, correlation between these two tests of smallintestinal function and the small-intestinal biopsy appearances.

Electron-microscope studies on a sample of the smallintestinal biopsy specimens have shown normal epithelial cells with intact microvilli even in two specimens showing partial villous atrophy.

Histochemical observations on a small sample of the smallintestinal biopsy specimens suggest that certain enzymes may be deficient during an attack of ulcerative colitis.
Observations on small-intestinal motility have shown some differences between ulcerative colitis patients and control subjects.

Superficial gastritis is found in a minority of patients with ulcerative colitis. It shows a less pronounced correlation with the activity of the ulcerative colitis than do the villous abnormalities of the small intestine.

Repeat observations have been made on 10 patients with ulcerative colitis after a lapse of time varying from 2 to 14 months from their original examination. The small-intestinal mucosa almost always showed improvement when the patients were re-examined during complete remission of the ulcerative colitis. By contrast, two patients whose ulcerative colitis was more severe at the time of re-examination than originally showed increased villous abnormalities in the small intestine. The small-intestinal mucosa is therefore in a highly plastic state in ulcerative colitis and swings from normality to villous abnormality in parallel with the inflammatory changes in the colon.

\section{REFERENCES}

Caulfield, J. B. (1957). 7. biophys. biochem. Cytol., 3, 827.

Chaudhary, N. A., and Truelove, S. C. (1962). Quart. F. Med., 31, 307. Groisser, V. W., and Farrar, J. T. (1962). Amer f. dig. Dis., 7, 57.

Padykula, H. A., Strauss, E. W., Ladman, A. J., and Gardner, F. H. (1961). Gastroenterology, 40, 735.

Palade, G. E. (1952). f. exp. Med., 95, 285.

Poole, J., and Salem, S. N. (1965). Awaiting publication.

Ryan, T. J., Vickers, H. R., Salem, S. N., Callender, S. T., and Badenoch, J. (1964). Brit. F. Derm., 76, 555.

Salem, S. N., Salt, R. D., and Truelove, S. C. (1965). Gut. In press.

Truelove, S. C., and Richards, W. C. D. (1964). Brit. med. \%., $1,394$.

Sammons, H. G., Frazer, A. C., Gompertz, S. M., and Morgan, D. B. (1962). Malabsorption Syndrome. Symposium 2nd World Congress of Gastroenterology, Munich, 19 May.

Santini, R., jun., Sheehy, T. W., and Martinez-de-Jesus, J. (1961). Gastroenterology, 40, 772 .

Shearman, D. J. C., Girdwood, R. H., Wynn Williams, A., and Delamore, I. W. (1962). Gut, 3, 16.

Shiner, M., and Birbeck, M. S. C. (1961). Ibid., 2, 277.

van der Kamer, J. H., Huinink, H. ten B., and Weyers, H. A. (1949). f. biol. Chem., 177,347 .
- An abridged version of a paper read at the annual conference of the Association of Probation Officers at Corpus Christi College, Cambridge, on 12 September 1964.

† Physician Deputy Superintendent, Horton Hospital, Epsom, Surrey; Gwilym Gibbon Fellow, Nuffield College, Oxford. received into prison for mental observation and reports to court who have been in a psychiatric hospital within twelve months of reception. The figures amount to an alarming total of 384 for 1963. They are often schizophrenics with some residual impairment, psychoneurotics, or psychopaths."

The numbers so remanded in England and Wales have increased from 6,366 in 1961 to 7,881 in 1963, and the number of hospital orders made has risen correspondingly from 838 to 1,043. But these orders are made after prosecution. The main purpose of this paper is to draw attention to the unprosecuted offenders. There is evidence from personal inquiries from mental hospitals, including Horton, which admit this type of offender as emergencies from Metropolitan London that they too have increased in numbers. But as they do not appear in official criminal statistics they might therefore be omitted from any assessment of the size and nature of the overall problem of the mentally abnormal offender. 


\section{Mode of Admission}

The following sections of the Mental Health Act, 1959, were invoked in the admission as emergencies of 78 unprosecuted male offenders in 1961 and 1962 to Horton Hospital, Epsom, whose catchment area lies entirely within Metropolitan London. Of these, three had been admitted since in similar circumstances, so that there are 75 individual cases.

1. "Informal" Admission-that is, where the offenders are not unwilling to be admitted to mental hospitals. Ten cases were so admitted.

2. Sections 25 and 29-that is, compulsory admission for observation to a mental hospital for 28 days in the former, and for 72 hours in a case of "urgent necessity" in the latter. Nineteen cases were admitted under one or other of these sections.

3. Section 136-that is, if a constable finds a person who appears to be mentally disordered and in immediate need of care and control in a place "to which the public have access" he may remove him to a place of safety-for example, a mental hospital-where he may be detained for not more than 72 hours. This section is particularly important because it is the only one which does not require medical intervention in order to admit a person to a mental hospital. Forty-nine cases were so admitted.

\section{Nature of Offences}

The offences alleged to have been committed by those admitted as emergencies under the new Act in 1961 and 1962 are classified in Table I.

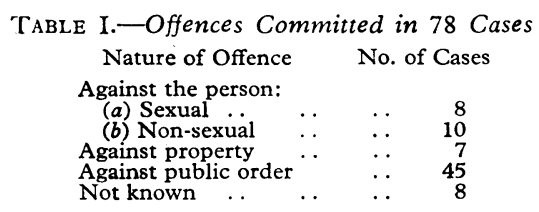

The offences of a sexual nature were in all cases concerned with indecent exposure, including five cases in which the offenders stripped themselves of their clothing, and appeared naked in public. The offences of a non-sexual sort included four assaults on the police. Those against property were mainly of larceny. It will be noted that the majority of the offences (45: $58 \%$ ) were against public order. The character of these particular offences was mixed, but all of them could be calculated to cause alarm or at least embarrassment to the ordinary citizen.

By and large most of the offences, however classified, had a certain bizarre quality, because of which there could have been little doubt in the minds of the police that they were committed by persons seriously deranged and in need of immediate care and control. In bringing this about there can be no doubt that in the vast majority of cases their action was fully justified.

A few examples will illustrate this point. The accounts of the offences are taken verbatim from the police reports accompanying the offenders to hospital.

Case 1.-Had delusions that he was the Messiah, and, as he did not get recognition, removed his clothes and walked naked down Charing Cross Road.

Case 2.-Taken from a Baker Street shop after tearing off his clothes.

Case 3.-Entered the House of Commons in order to dispense British justice.

Case 4.-Walking round Regent's Park dressed in a fur coat claiming to be an ape.

Case 5.-Driving a car in an erratic way. When stopped ran all over the road and shouted babbling nonsense.

Case 6.-Went beserk in National Assistance Board office. Assaulted two P.C.s.

\section{Clinical Diagnosis}

The clinical diagnosis of the 75 individual offender-patients was: schizophrenia in 59 cases, affective disorder in 3, organic disorders in 3, psychopathy in 3, and addictions in 8 . Schizophrenia is seen to be by far $(78 \%)$ the most common single mental illness manifested, and accounts in all probability for the bizarre quality inherent in so many of the offences. The inference, too, is that offences against public order are more frequently committed by schizophrenics than by any other single clinical group.

\section{Age of Offenders}

The age of the offender-patients is given in Table II: 63 $(84 \%)$ are under 50 years of age, compared with $62 \%$ of the general male population in the same age group (RegistrarGeneral's mid-year estimate for 1962). The high incidence of cases in this age-group and the $22 \%$ difference compared with the national average are consistent with the overwhelming preponderance of schizophrenia, which in its active phase is a disease of young adulthood and early middle-age.

TABLE II.-Ages of the 75 Offenders

\begin{tabular}{ll|l|c|c|c|c|c|c|c|c}
\hline Age & $\cdots$ & $\ldots$ & -19 & $20-29$ & $30-39$ & $40-49$ & $50-59$ & $60-69$ & $70-79$ & N.K. \\
No. &. &.. & 3 & 20 & 26 & 14 & 10 & - & 1 & 1 \\
\hline
\end{tabular}

\section{Chronicity of the Psychoses}

Because these cases were admitted as emergencies it might be assumed that their mental illness was itself of sudden onset. Clinical investigation, however, revealed that in most cases their illness was in fact of long standing. This conclusion was reinforced by data obtained from the clinical records of Horton and other civilian hospitals in which offenders had been previously treated. The data are incomplete because of the notorious difficulty of compiling a comprehensive psychiatric history in any series of cases. Furthermore, only data from hospitals in the United Kingdom were included, although it was known that some of the immigrants included in the series had been psychotic, and some had received treatment in the countries of their origin. Nevertheless, Tables III and IV, which are complementary, illustrate the history of previous mental illness in $53(70 \%)$ of the cases. Table III gives the number of previous admissions to mental hospitals, while Table IV shows the total length of time previously spent in them.

From these two tables it can be seen that $43(81 \%)$ of the 53 cases had had multiple admissions to mental hospitals, and $27(51 \%)$ had spent an aggregate of more than six months in them. Clinically, therefore, it is a fair assumption that a high proportion of these cases were in fact suffering from chronic (or "long-term" to use the fashionable idiem) psychosis or, to be more precise, chronic schizophrenia.

The individual mental hospitals other than Horton in which these 53 cases had been previously treated numbered 51 in England, Scotland, Wales, and Northern Ireland. But an individual case may have done the rounds of as many as 10

TABLE III.-Previous $\begin{gathered}\text { Recorded Mental-hospital Admissions in } 53 \\ \text { Unprosecuted Offenders }\end{gathered}$

\begin{tabular}{ll|r|r|r|r|r|r|r|r}
\hline $\begin{array}{l}\text { No. of admissions } \\
\text { No. of cases }\end{array}$ &.. & 1 & 2 & 3 & 4 & 5 & $6-10$ & $11-20$ & $20+$ \\
\hline
\end{tabular}

TABle IV.-Total Period Previously Spent in Mental Hospitals by 53 TABle IV.-Total Period Previously Spent in

\begin{tabular}{|c|c|c|c|c|c|c|}
\hline $\begin{array}{l}\text { Period } \\
\text { No. . . }\end{array}$ & . & $<6$ months & 6-12 months & $\begin{array}{c}1-5 \text { years } \\
20\end{array}$ & $6-10$ years & $>10$ years \\
\hline
\end{tabular}


of these hospitals-a sort of psychiatric musical chairs as it were. A further fact emerges from these data-namely, that London, for a variety of reasons, is becoming increasingly a sump into which chronic psychotics from all over the United Kingdom, and indeed much further afield, are drained.

\section{Disposal}

The avenues whereby the 78 admissions left hospital were analysed for a period until the end of the year following the year of their admission-that is, up to the end of December 1962 or 1963 for those admitted in 1961 and 1962 respectively. Twenty-two $(28 \%)$ absconded or left against advice. Eight $(10 \%)$ were either repatriated or transferred to other hospitals nearer their homes ; one patient died, and seven $(9 \%)$ remained in hospital. The other $40(51 \%)$ had improved sufficiently to be discharged by the medical officer concerned.

The absconders are noteworthy not only for the numbers involved but also because those who did so were quite often seriously disturbed. This underlines yet again the difficulty or impossibility of preventing abscondence from mental hospitals which subscribe to the policy of more freedom and less security, or in which the milieu is more therapeutic than custodial.

\section{Social Failure of the Offender-patients}

One index of the social failure of these offender-patients is the length of time they were able to survive in the community after discharge from mental hospitals before coming into collision with the police. Table $\mathrm{V}$ gives this information in respect of the 53 offenders with a known previous record of mentalhospital treatment. Three individual cases had twice been admitted in similar circumstances in the two-year period under survey and therefore appear twice in the table.

\begin{tabular}{|c|c|c|c|c|c|c|}
\hline $\begin{array}{ll}\text { [nterval } & \ldots \\
\text { No. } & .\end{array}$ & $<\begin{array}{c}1 \text { week } \\
13\end{array}$ & $1-4$ weeks & $1-6$ months $_{13}$ & 6-12 months & 1-2 years & $\underset{7}{2 \text { years }+}$ \\
\hline
\end{tabular}

What is outstanding is the number of cases $(23 \%)$ incapable of survival for even as long as a week. In fact, in five instances arrest by the police occurred on the actual day of discharge. What is equally to be noted is that Horton was the last hospital in which rather less than half the cases ( 27 out of 56) had been treated. The rest had been in other hospitals and had drifted into Horton's catchment area. As they had no fixed abode when apprehended their address was technically the police station to which they were taken pending arrangements for their conveyance to Horton.

\section{Previous Criminal Records of Unprosecuted Offenders}

In my previous paper (Rollin, 1963) I wrote: “ Mental illness and antisocial behaviour are by no means mutually exclusive. Indeed, some of the offenders had long criminal records, and could be rightly classified as professional criminals." At that time it was impossible to be more precise regarding the real extent of the criminal records, individual or collective, of offenders admitted to mental hospitals, but with the generous co-operation of the Home Office Research Unit and the Criminal Records Office this deficiency has largely been made good. The information obtained from this source contains details of mainly indictable offences, and does not usually include offences for which no prosecution but admission to mental hospitals results. Additional data concerning the latter were in some instances gleaned from the hospitals concerned when they could be traced.
It emerges from the data now available that of the present unprosecuted offenders under review $30(40 \%)$ had criminal records-that is, they had been proved guilty of offences after trial in court. In some instances other offences were taken into account at the time of trial, or charges were brought of associated offences arising out of the original charge. For the purposes of simplification where this occurred they are calculated as one offence. With this proviso, which if anything tends to minimize their criminal records, it was found that of the 30 with such records the number of actual offences committed ranged from one in three cases to between 11 and 20 in five cases. Of those found guilty $21(70 \%)$ had served prison sentences ranging from one sentence in seven cases to two who had served over 11 sentences. Table VI sets out the distribution of offences and prison sentences.

Table VI.-Distribution of Previous Offences and Prison Sentences in

\begin{tabular}{|c|c|c|c|c|}
\hline \multicolumn{3}{|c|}{ No. } & Offences & Prison Sentences \\
\hline $\begin{array}{l}1 \\
2-5 \\
6-10 \\
11\end{array}$ & $\begin{array}{l}\cdots \\
\because \\
\therefore\end{array}$ & $\begin{array}{l}\cdots \\
\cdots \\
\cdots\end{array}$ & $\begin{aligned} 3 & \text { cases } \\
17 & \Rightarrow \\
5 & \Rightarrow \\
5 & \Rightarrow\end{aligned}$ & $\begin{array}{l}7 \text { cases } \\
9 \\
3 \\
2 ”\end{array}$ \\
\hline & otal & $\cdots$ & 30 ", & $21 "$ \\
\hline
\end{tabular}

The outstanding feature in this table is the extremely high proportion of recidivists $(90 \%)$, or $36 \%$ of the total number of the cases under consideration on whom repeated prison sentences have had no deterrent or corrective effect.

\section{Careers of Unprosecuted Offenders Subsequent to Their Discharge from Hospital}

In order to obtain something approaching an overall picture of the social problem presented by these particular mentally abnormal offenders it was considered essential to study their fate after discharge from hospital. To this end an attempt was made to trace their post-discharge careers from both a psychiatric and a criminological standpoint. The follow-up was until the end of March 1964. At this point in time there were still seven cases remaining in Horton of those originally admitted. Thus 68 cases were "at risk" for periods varying from 15 months for those admitted at the end of 1962 to 39 months for those admitted at the beginning of 1961 .

\section{Psychiatric Follow-up}

Only in those cases readmitted to Horton was a full followup possible. For the rest the same difficulties were experienced as was the case in attempting to trace their histories before admission. Despite these admitted shortcomings data were obtained of readmission to mental hospitals, not as the result of police action, in 21 cases (31\%). Of these, 13 had been readmitted once, seven readmitted two to five times, and in one case there had been six readmissions.

\section{Criminological Follow-up}

The information for this follow-up of the 68 cases "at risk" (again to the end of March 1964) was obtained from the same sources as in the study of their previous criminal recordsnamely, the Home Office Research Unit, the Criminal Records Office, and Horton and other mental hospitals.

From these data it was ascertained that 28 (41\%) of the cases "at risk" had subsequently committed offences. Eighteen had been guilty of one offence, nine were guilty of two to five offences, and one of seven offences. The offences were varied and not necessarily in the same category as the one leading to their key admission to Horton. 
The way in which these offences were dealt with by the police or the judiciary was also varied. For 16 of the offences the offenders were admitted to mental hospitals (three on two occasions) either after prosecution or otherwise. In 10 instances prison sentences were awarded (twice in two cases, three times in two cases, and in one case the offender had had five sentences). Seven offences had been dealt with in other waysthat is, by fines, absolute discharge, or probation orders. In several instances the same offender had been dealt with in different ways for different offences-for example, three had been committed to mental hospital for one offence and to prison for another.

\section{Relation of Previous to Subsequent Careers of Unprosecuted Offenders}

In order to obtain a more comprehensive assessment of the social competence, or rather incompetence, of this group of mentally abnormal offenders it is obviously necessary to relate their careers before and after their key admission to Horton in terms of offences and mental-hospital admissions. Table VII summarizes the findings. The vertical columns refer to their previous careers. Column 1 shows that 31 (41\%) had had mental-hospital admissions but no criminal record. Eight (11\%) had criminal records only (column 2); and column 3 shows that $22(29 \%)$ had both mental-hospital admissions and criminal records. Only $14(19 \%)$ had had neither one nor the other (column 4).

\begin{tabular}{|c|c|c|c|c|c|}
\hline \multirow[b]{3}{*}{ Subsequent Careers } & & Previous & Careers & & \multirow[b]{3}{*}{ Total } \\
\hline & 1 & 2 & 3 & 4 & \\
\hline & $\begin{array}{c}\text { Mental- } \\
\text { hospital } \\
\text { Admissions } \\
\text { Only }\end{array}$ & $\begin{array}{l}\text { Offences } \\
\text { Only }\end{array}$ & $\begin{array}{c}\text { Both } \\
1 \text { and } 2\end{array}$ & $\begin{array}{l}\text { Neither } \\
1 \text { nor } 2\end{array}$ & \\
\hline 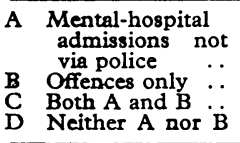 & $\begin{array}{r}10 \\
3 \\
2 \\
16\end{array}$ & $\begin{array}{l}\overline{5} \\
\overline{3}\end{array}$ & $\begin{array}{r}1 \\
10 \\
6 \\
5\end{array}$ & $\frac{1}{1}$ & $\begin{array}{r}12(16 \%) \\
18(24 \%) \\
9(12 \%) \\
36(48 \%)\end{array}$ \\
\hline Total & $31(41 \%)$ & $8(11 \%)$ & $22(29 \%)$ & $14(19 \%)$ & 75 \\
\hline
\end{tabular}

The horizontal columns refer to their subsequent careers. Column A shows that $12(16 \%)$ were readmitted to mental hospitals without the intervention of the police. Column B shows that $18(24 \%)$ had committed offences and were dealt with in a variety of ways, which may have included prison sentences and/or readmission to mental hospitals under Part IV or $\mathrm{V}$ of the Act. Column $\mathrm{C}$ shows that $9(12 \%)$ had been readmitted to mental hospital and had also committed offences. Taking Columns $\mathrm{A}, \mathrm{B}$, and $\mathrm{C}$ together, the conclusion arrived at is that $39(52 \%)$ had failed to survive in society even for the limited period of the follow-up without either further care in a mental hospital or the commission of further crimes, or without both. Furthermore, if the previous and subsequent careers are taken together (columns 4 and D), then in only 12 cases $(16 \%)$ was there a " nil " record in respect of both mentalhospital admissions and offences. In other words, for the other 63 cases $(84 \%)$, the admission to Horton was only one chapter in an unhappy biography highlighted by mental-hospital admissions interspersed with court appearances, leading in many cases to terms of imprisonment.

\section{Comparison Between the Unprosecuted and Prosecuted Offenders}

The prosecuted mentally abnormal offenders are the subject of a separate study, but it would be pertinent at this point to compare them briefly with the unprosecuted offenders. It must be emphasized that the two groups are by no means selfcontained. It happens not infrequently that the same individual is admitted on one occasion as a prosecuted case and on another as an unprosecuted, or vice versa.

Clinically, both groups show an overwhelming preponderance of schizophrenics, but as a group the unprosecuted cases are more seriously and chronically disturbed. This is reflected, too, in the follow-up, which shows that more of these cases are returned to mental hospitals.

From a criminological standpoint the reverse situation obtains-that is, there is as a group a more serious record of crime in the prosecuted cases than in the unprosecuted, and in the follow-up there are seen to be more convictions and prison sentences in the former than in the latter.

What is of particular interest is that comparing the crimes committed leading to prosecution or otherwise-that is, action under Part V or Part IV respectively-there is a significantly higher incidence of crimes against property in the first than in the second ( $38 \%$ compared with $9 \%$ ). Conversely, in offences against public order there is a higher incidence among the unprosecuted compared with prosecuted (58\% and $43 \%)$. These differences might be explained in terms of the wholesome respect paid to property in our culture, offences against which occasion therefore more prosecutions; or it might be that acquisitive crimes appear more purposeful and therefore imply more blameworthiness. On the other hand, the offences against public order have so often an inherent bizarre quality that the police can have little doubt that they are dealing with persons obviously deranged and therefore less blameworthy; admission to mental hospital without prosecution results.

\section{Commentary}

The undoubted increase in the number of prosecuted offenders admitted to mental hospitals since the implementation of the Mental Health Act, 1959, has been paralleled by an increase in the number of admissions of unprosecuted offenders. The two modes of admission are by no means mutually exclusive: an individual offender-patient may be admitted on one occasion after prosecution, and without prosecution-that is, as an emergency-on another.

A diagnosis of chronic schizophrenia was made in the great majority of the unprosecuted offenders. Their social incompetence is manifest in their psychiatric and criminological records both before and after the key admission to Horton Hospital. This event, indeed, is only one chapter in a tragic biography highlighted by mental-hospital admissions interspersed with appearances in court, leading in many cases to terms of imprisonment. Furthermore, it is patently evident that there is a hard core of mentally abnormal offenders who are incorrigible in terms of the penal system and incurable in terms of the mental-hospital system. A solution to the social problem they pose cannot be found in the present procedure whereby they are shunted in an almost arbitrary way between one system and the other.

Two further facts also emerge from the inquiry. The first relates to the lack of adequate aftercare facilities for chronic psychotics recently discharged from mental hospitals, in the London area at least. The second stems from the high proportion of absconders: those absconding are not infrequently the most disturbed and potentially the most dangerous. The grave risk is exposed of committing these people to conventional mental hospitals where there is at best only token security.

\section{Summary}

Seventy-eight unprosecuted male offenders were admitted in 1961 and 1962 to Horton Hospital, Epsom, the catchment area of which lies within Metropolitan London. 
Of $53(67 \%)$ who had a recorded history of previous mental illness, 43 had had multiple admissions to mental hospitals and 27 had spent an aggregate of over six months in them. Schizophrenia was diagnosed in $59(78 \%)$ cases.

Official records reveal that $30(4.0 \%)$ of the cases had criminal records. Of these, 27 had committed more than one indictable offence, and 21 had served prison sentences ranging from one sentence in seven cases to two who had served over 11 sentences.

A psychiatric and criminological follow-up for a limited period was made of those who had been discharged or had left hospital. Of the 68 cases "at risk," 21 (31\%) had been readmitted to mental hospitals, not as the result of police action. Twenty-eight ( $41 \%$ ) had committed further offences, not necessarily in the same category as the one discussed. The disposal of the subsequent offences was varied and included readmission to mental hospital and prison sentences.

The group differences between those admitted as either prosecuted or unprosecuted cases are briefly stated.
Comment on the adverse social sequelae of certain aspects of the present system of dealing with mentally abnormal offenders is made.

I would like to express my gratitude to the Warden and Fellows -particularly Dr. Nigel Walker-of Nuffield College, Oxford, for the facilities provided by them during my tenure of the Gwylim Gibbon Research Fellowship. I am deeply indebted to the Home Office Research Unit, and the Criminal Records Office, and to the Governors, Medical Officers, and Officers of H.M. Prisons for their invaluable co-operation. My thanks are due, too, to the many hospitals who answered my inquiries. My special thanks to Miss E. Briggs, of Horton Hospital, for her unstinting help, and to Dr. J. H. Watkin, of the same hospital, for permission to publish this paper.

\section{REFERENCES}

Prisons and Borstals, Report on the work of the Prison Department in the year 1963 (1963), p. 57. H.M.S.O., London. Cmnd. 2381. Rollin, H. R. (1963). Brit. med. F., 1, 786.

\title{
Occurrence of Bullous Lesions in Acute Barbiturate Intoxication
}

\author{
G. W. BEVERIDGE,* M.B., M.R.C.P.ED. ; A. A. H. LAWSON, † M.B., M.R.C.P.ED.
}

[With Special Plate]

Brit. med. F., 1965, 1, 835-837

In spite of the fact that the cutaneous manifestations of sensitivity to barbiturates are extensively documented, the occurrence of bullous lesions in patients suffering from acute barbiturate intoxication appears to have received little recognition. The following study was undertaken in order to determine the incidence and possible specificity of these lesions.

\section{Patients and Methods}

During the period from 1 October 1963 to 30 June 1964 there were admitted to the regional poisoning treatment centre in the Royal Infirmary of Edinburgh 290 patients with barbiturate overdosage and 69 with overdosage from other sedative drugs such as phenothiazine derivatives and non-barbiturate hypnotics. In the patients who were thought to be suffering from barbiturate intoxication, and in all those with impairment of consciousness and in whom the nature of the ingested poison was obscure, the diagnosis was confirmed by analysis of serum for barbiturate (Wright and Johns, 1953). During the initial assessment all the cases were carefully examined for cutaneous lesions. The level of consciousness was recorded, using a system of grading similar to that used by Reed et al. (1952); and in all cases the regime of therapy adopted was similar to that advocated in the treatment of barbiturate poisoning by Nilsson (1951) and by Plum and Swanson (1957).

Where there was evidence of respiratory insufficiency assessment was made by an anaesthetist ; an endotracheal tube was inserted and where necessary the patient was maintained on a respirator. Patients requiring these measures are recorded in Table II as suffering from severe respiratory insufficiency. Patients were regarded as hypotensive when the systolic blood-

\footnotetext{
* Senior Registrar, Department of Dermatology, Royal Infirmary, Edin-

† Senior House Officer, Regional Poisoning Treatment Centre, Royal Infirmary, Edinburgh.
}

pressure was less than $100 \mathrm{~mm} . \mathrm{Hg}$ in those over the age of 55 and less than $90 \mathrm{~mm}$. $\mathrm{Hg}$ in the others. When hypotension was present the blood-pressure was maintained just above these levels by raising the foot of the bed, and in severe poisonings by intramuscular or continuous intravenous infusions of metaraminol (Aramine). All patients were maintained in a state of adequate hydration. The pulse, blood-pressure, and respiratory state were recorded at half-hourly intervals.

Every two hours the patients were turned by the nursing staff and examined for the development of any skin lesions, and in particular blister formation. If any were noted these were recorded and confirmed by a doctor. Each patient was examined carefully by a doctor at eight-hourly intervals, and when skin lesions were noted these were also assessed by one of us (G.W.B.). The time of appearance, nature, and site of all cutaneous lesions were recorded.

In 15 patients who developed bullae the following additional investigations were carried out. Liver and renal function were assessed by the conventional tests. When the patients had recovered from the effects of poisoning a challenging dose of the barbiturate ingested was given orally in the normal therapeutic dose. Patch tests were applied to the skin of the forearm, using phenobarbitone, amylobarbitone, pentobarbitone as a $10 \%$ aqueous solution of each drug, and a piece of capsule from Nembutal (pentobarbitone sodium).

\section{Results}

During the course of the investigation definite bullous lesions were noted in $19(6.5 \%)$ out of the 290 patients suffering from barbiturate intoxication (Table I). With one exception these lesions had made their appearance within 24 hours of ingestion of the drug. No blisters developed in the group of patients who had ingested other sedative drugs. 